\title{
Human papillomavirus vaccination: the population impact
}

\section{[version 1; peer review: 3 approved]}

\author{
Lai-yang Lee ${ }^{1,2}$, Suzanne M. Garland ${ }^{1-4}$ \\ ${ }^{1}$ Department of Microbiology and Infectious Diseases, Royal Women's Hospital, Parkville, Victoria, Australia \\ 2Department of Microbiology, Royal Children's Hospital, Parkville, Victoria, Australia \\ ${ }^{3}$ Department of Infection and Immunity, Murdoch Childrens Research Institute, Royal Children's Hospital, Victoria, Australia \\ ${ }^{4}$ Department of Obstetrics Gynaecology, University of Melbourne, Parkville, Victoria, Australia
}

V1 First published: 12 Jun 2017, 6(F1000 Faculty Rev):866

https://doi.org/10.12688/f1000research.10691.1

Latest published: 12 Jun 2017, 6(F1000 Faculty Rev):866

https://doi.org/10.12688/f1000research.10691.1

\section{Abstract}

We currently have the knowledge and experience to prevent much of human papillomavirus (HPV)-related disease burden globally. In many countries where prophylactic HPV vaccination programs have been adopted as highly effective public health programs with good vaccine coverage, we are already seeing, in real-world settings, reduction of vaccine-related HPV-type infections, genital warts and cervical precancers with potential reductions in vulvar, vaginal and anal precancers. Moreover, we are seeing a change in cervical screening paradigms, as HPV-based screening programs now have strong evidence to support their use as more sensitive ways to detect underlying cervical abnormalities, as compared with conventional cervical cytology. This article describes the impact of prophylactic vaccination on these outcomes and in settings where these vaccines have been implemented in national immunisation programs. Given the successes seen to date and the availability of essential tools, there has been a global push to ensure that every woman has access to effective cervical screening and every girl has the opportunity for primary prevention through vaccination. A gender-neutral approach by offering vaccination to young boys has also been adopted by some countries and is worthy of consideration given that HPV-related cancers also affect males. Furthermore, vaccination of young boys has the advantage of reducing the risk of HPV transmission to sexual partners, lowering the infectious pool of HPV in the general population and ultimately HPV-related diseases for both genders. Therefore, it is appropriate that all countries consider and promote national guidelines and programs to prevent HPV-related diseases.

Keywords

HPV vaccination, prophylactics, cervical cancer, prevention

\section{Open Peer Review}

Approval Status

1

2

3

version 1

12 Jun 2017

Faculty Reviews are review articles written by the prestigious Members of Faculty Opinions. The articles are commissioned and peer reviewed before publication to ensure that the final, published version is comprehensive and accessible. The reviewers who approved the final version are listed with their names and affiliations.

1. Eileen Dunne, Centers for Disease Control and Prevention, Atlanta, USA

Thailand MOPH CDC Collaboration, Bangkok, Thailand

2. Linda Niccolai, Yale School of Public Health, New Haven, USA

3. Mark Jit, London School of Hygiene and Tropical Medicine, London, UK Public Health England, London, UK Any comments on the article can be found at the end of the article. 
Corresponding author: Suzanne M. Garland (Suzanne.garland@thewomens.org.au)

Competing interests: SG has received speaking fees from Merck Sharp \& Dohme (MSD) and Sanofi Pasteur MSD for work performed in her personal time. Merck paid for her travel and accommodation to present at HPV Advisory Board meetings. Lai-yang Lee declares that she has no competing interests.

Grant information: SG has received grants to her institution from the Commonwealth Department of Health for HPV genoprevalence surveillance post-vaccination, Merck and GlaxoSmithKline to perform phase 3 clinical vaccine trials, Merck to evaluate HPV in RRP postvaccination program, Seqirus Australia for funding of the Australian Cervical Cancer Typing Study, and the Victoria Cancer Agency for a study on monitoring and effectiveness of the Australian cervical cancer program, a translation to reduction in vaccine-related HPV infection and pre-cancerous cervical lesions study (the Vaccine Against Cervical Cancer Impact and Effectiveness study) plus a study on associations and typing of early-onset cancers in young women.

Copyright: @ 2017 Lee Ly and Garland SM. This is an open access article distributed under the terms of the Creative Commons Attribution License, which permits unrestricted use, distribution, and reproduction in any medium, provided the original work is properly cited.

How to cite this article: Lee Ly and Garland SM. Human papillomavirus vaccination: the population impact [version 1; peer review: 3 approved] F1000Research 2017, 6(F1000 Faculty Rev):866 https://doi.org/10.12688/f1000research.10691.1

First published: 12 Jun 2017, 6(F1000 Faculty Rev):866 https://doi.org/10.12688/f1000research.10691.1 


\section{Introduction}

Human papillomavirus infection and disease association

Human papillomavirus (HPV) is the commonest sexually transmitted infection, and the resultant diseases have significant morbidity and mortality ${ }^{1}$. Although most HPV infections are transient, persistent infections are a prerequisite for pre-cancerous lesions and ultimately cancer. ${ }^{2-5}$. It is highly likely that latent infection (as infection dormant in the basal cells not readily detectable by diagnostic assays, but reversible) ${ }^{6}$ or subclinical infections (or both) exist and this is particularly relevant when an individual is immunocompromised since it increases the risk of developing symptomatic disease. Oncogenic HPVs were shown by Harald zur Hausen to be the causative agent of cervical cancer in the early 1980s by virtue of molecular epidemiology; for this work, zur Hausen shared the Nobel Prize in Physiology or Medicine in $2008^{7}$. Of the many genotypes specifically infecting the anogenital area, HPV16 and HPV18 are the commonest high-risk or oncogenic genotypes in cervical cancer and are responsible for approximately 50\% of high-grade cervical dysplasias and $70 \%$ of cases of cervical cancer, the fourth most common cancer in females globally ${ }^{8,9}$. Oncogenic HPVs cause almost $100 \%$ of cervical cancers, $90 \%$ of anal, $70 \%$ of vaginal, $40 \%$ of vulvar, $50 \%$ of penile and $13 \%$ to $72 \%$ of oropharyngeal cancers, and HPV16 predominates in all of these non-cervical HPV-related cancers. HPV6 and HPV11, which are classified as low-risk genotypes, cause $90 \%$ of genital warts as well as the rare but debilitating recurrent respiratory papillomatosis $(\mathrm{RRP})^{10,11}$.

\section{Prophylactic human papillomavirus vaccines}

Given the heavy disease burden of cervical cancer, prophylactic HPV vaccines were developed to target the commonest high- and low-risk HPV genotypes. Two such vaccines were first licensed for clinical use in 2006 following phase 3 clinical trials, which showed efficacy, safety and immunogenicity against vaccine-related HPV types ${ }^{12-15}$. Currently available vaccines now include bivalent (2vHPV and targets HPV 16/18) (2,13 $^{12}$, quadrivalent (4vHPV and targets HPV 16/18/6/11) ${ }^{14,15}$ and nonavalent (targets HPV 16/18/6/11 as well as the five next most common oncogenic types found in cervical cancers, 31/33/45/52/58) vaccines ${ }^{16}$. Whilst many countries have licensed these vaccines, worldwide introduction into national immunisation programs differs by country, and some vaccines are available only on a user-pays basis and therefore entail an out-of-pocket expense. This has contributed to the resultant generally poor and inequitable uptake. For the greatest impact of these vaccines, the aim is to vaccinate adolescent females prior to sexual debut and to gain high coverage of the target population ${ }^{9}$. Some countries have implemented catch-up programs for older females or routine vaccination of adolescent males (or both) to increase overall population coverage and enhance herd protection ${ }^{17}$.

\section{Vaccine effectiveness and impact}

Clinical trials indicated efficacy of the vaccines against the HPV types included in the respective vaccines as well as some modest cross-protection against some non-vaccine but phylogenetically related strains (HPV 31, 33 for HPV16-related types and HPV45 for 18-related types ${ }^{12,18}$. The true benefit of vaccination can be seen only from real-life impact and effectiveness once vaccination has been included in public health programs. To appreciate this requires good surveillance and observation of changes in genoprevalence within vaccine-eligible age cohorts as well as of disease outcomes. Some of the challenges here have included the fact that HPV cannot be cultured by traditional means, so DNA typing in the general community before and after vaccination is required to determine molecular genoprevalence. Although a number of assays to determine the presence of HPV are currently available ${ }^{19}$, their appropriateness is based on whether they are meant to be used for clinical needs (to detect underlying disease in which case assays are designed with clinical cut-offs and are less sensitive) or for pure epidemiological purposes (these use analytical viral endpoints and are highly sensitive $)^{20,21}$. Furthermore, as HPV infection is not notifiable, nor are many of the associated clinical manifestations in most countries, individual surveillance systems have been required to measure the impact and effectiveness of the vaccines. In addition, as the times from infection to the various disease manifestations differ and may be weeks to months (genital warts) to years (precancers) or decades (cancer), the impact of vaccination on each disease varies. Consequently, in the 10 years since the introduction of both $4 \mathrm{vHPV}$ and $2 \mathrm{vHPV}$ vaccines, measures of vaccine impact have largely been determined by individual observational studies in countries with higher vaccine coverage, although a number of large, countrywide surveillance activities are now occurring. Thus, a direct comparison between the multiple studies published to date is complicated as the population studied, the duration of study and the endpoints observed or measured (or both) differ. Monitoring impact is difficult, particularly as some endpoints such as precancerous lesions require a robust pre-cancer screening program to be in place or are not notifiable or have a prolonged interval between infection and development of diseases, particularly for cancers which usually occur after decades of persistent infection with a high-risk HPV type.

In this article, we define vaccine impact as the effect of public health programs of HPV vaccines at a population level and the measurement thereof of reduction in disease burden (before and after initiation of a vaccination program) and largely focus on this. In contrast, vaccine effectiveness is examined at an individual level ${ }^{22}$. It is largely observational and determines the effect of vaccination observed in populations after a program commences and compares outcomes in those vaccinated with those unvaccinated.

Vaccine impact will be determined by the type of vaccine program (an ongoing routine vaccination program to a specific age group versus inclusion of a catch-up program which may be limited in time and/or target a narrow or wide number of age cohorts), vaccine coverage, which population is targeted (for example, a program focused entirely on females, a gender-neutral approach, or targeted vaccination such as the HIV-positive population), the duration of vaccine protection, the duration of follow-up after vaccination, and type of surveillance, if any, of various outcome measures.

\section{Vaccine impact on human papillomavirus infection}

Australia was one of the first countries to implement a fully government-funded, population-based HPV vaccination program. It commenced in 2007 as an ongoing school-based program with a three-dose course of the 4vHPV vaccine, targeting females in the first year of high school at age 12 to 13 years, with a catch-up for those ages 12 to 26 years until December $2009^{23}$. In 2013, the Australian 
government extended the program to include 12- to 13-year-old males, including a 2-year catch-up vaccination program for those ages 14 to 15 years $^{24,25}$. Overall, the program has been well received and high vaccine coverage rates have been achieved; the greatest rates have been from those within the school-based cohorts: over $70 \%$ have received all three doses for young girls and just under $70 \%$ have received all three doses for boys ${ }^{24-26}$. Consequently, Australian researchers were among the first to report reductions in the prevalence of vaccine-type HPV infections, by $86 \%$ in 18 - to 24 -year-olds who had received three vaccine doses and $76 \%$ for those who had received one or two doses ${ }^{22,27,28}$. In general, Tabrizi et al. found that the greatest decline in vaccine-type HPV prevalence corresponded to the age group which had the highest vaccine coverage, even in the unvaccinated but eligible-age population, highly suggestive of herd protection ${ }^{28}$. Furthermore, Australia is already seeing herd protection in young males as a result of the female program ${ }^{29}$.

Other countries that have achieved high coverage with $4 \mathrm{vHPV}$ or $2 \mathrm{vHPV}$ vaccines also report rapid and large declines in vaccinerelated HPV infections. For example, in Scotland, which also has a school-based program, which targets 12- to 13-year-old girls as an ongoing program and had a limited 3-year catch-up from 2008 to 2011 for 13- to 17 -year-olds, coverage rates for the $2 \mathrm{vHPV}$ vaccine have been even greater, at up to $90 \%$, and reported declines in vaccine-related infections were from $29.8 \%$ to $13.6 \%^{30}$. In contrast, in the USA, coverage of the $4 \mathrm{vHPV}$ vaccine has been much lower, at $40 \%$ for females and $22 \%$ for males; yet despite this, national impact studies from the USA 4 years after the introduction of HPV vaccines noted a $56 \%$ decrease in HPV vaccine types (from cervical-vaginal samples from 14- to 19-year-olds) $)^{31,32}$. Although the early vaccination initiation uptake rate was low (at 17\%) for females 19 to 26 years old in 2009, by 2012 the uptake in the USA had doubled to $34 \%$, resulting in a further $45 \%$ decrease in the prevalence of vaccine-type $\mathrm{HPV}^{33}$, or an overall $64 \%$ decrease in vaccine-type HPV prevalence after 6 years ${ }^{32}$. A less marked, but still significant, reduction of $34 \%$ prevalence over the same time frame was noted in the 20- to 24-year-old group ${ }^{32}$. In sexually active US women ages 14 to 24 in the post-vaccination era, those who had received at least one HPV vaccine dose had a $2.1 \%$ reduction of vaccine-type HPV prevalence compared with $16.9 \%$ in the same age group of unvaccinated women ${ }^{32}$.

\section{Genital warts}

Genital warts are a common condition, which affects up to $10 \%$ of the female population under 45 years old and which usually develops 2 to 3 months after infection with low-risk HPV genotypes, primarily HPV 6 and $11^{10,34}$. Australia was the first to report a reduction in genital warts, and the reduction was larger and faster than had been expected by researchers ${ }^{35,36}$, and the $4 \mathrm{vHPV}$ vaccine provided up to $92 \%$ reduction in HPV-associated genital warts ${ }^{37}$. Interestingly, observations from early use of $2 \mathrm{vHPV}$ vaccines noted an unexpected decrease in genital warts. It is speculated that this response is due to vaccination resulting in a cell-mediated immune response which confers a moderate amount of protection against some low-risk HPV types ${ }^{38,39}$.

Since the commencement of $4 \mathrm{vHPV}$ vaccination, there has been a substantial reduction in reports of genital warts in countries with 4vHPV vaccination programs (Table 1$)^{35-37,40-43}$. A Belgian study

Table 1. Summary of human papillomavirus vaccination programs, outcomes and cervical screening programs.

\begin{tabular}{|c|c|c|c|c|c|}
\hline & Australia & USA & United Kingdom & Denmark & Scotland \\
\hline Delivery route & School & Clinic & Mostly school & Clinic & School \\
\hline $\begin{array}{l}\text { HPV vaccine program } \\
\text { commencement }\end{array}$ & 2007 & 2006 & 2008 & 2009 & 2008 \\
\hline Vaccine type & $\begin{array}{l}\text { 4vHPV } \\
\text { Ongoing }\end{array}$ & $\begin{array}{l}\text { 4vHPV } \\
2006-2016 \\
9 v H P V \\
\text { December } 2016\end{array}$ & $\begin{array}{l}\text { 2vHPV } \\
2008-2012 \\
\text { 4VHPV } 2012\end{array}$ & 4vHPV & $\begin{array}{l}\text { 2vHPV } \\
2008-2012 \\
\text { 4VHPV } 2012\end{array}$ \\
\hline Three-dose schedule & Yes & & & & \\
\hline Two-dose schedule ${ }^{a}$ & No & Yes October 2016 & $\begin{array}{l}\text { Yes September } \\
2014\end{array}$ & Yes 2014 & Yes 2014 \\
\hline Females & Yes & Yes & Yes & Yes & Yes \\
\hline Target age, years & $12-13$ & $11-12$ & $12-13$ & 12 & $12-13$ \\
\hline Males (routine) & Yes from 2013 & Yes from 2011 & No & No & No \\
\hline $\begin{array}{l}\text { Target age males, } \\
\text { years }\end{array}$ & $12-13$ & $11-12$ & - & - & - \\
\hline
\end{tabular}




\begin{tabular}{|c|c|c|c|c|c|}
\hline & Australia & USA & United Kingdom & Denmark & Scotland \\
\hline Catch-up program & $\begin{array}{l}12-26 \text { ㅇ } \\
2007-2009 \\
14-15 \text { years old } \widehat{~} \\
2013-2015\end{array}$ & $\begin{array}{l}\text { 13-26 o } \\
\text { Ongoing }\end{array}$ & $\begin{array}{l}\text { Up to } 18 \text { o } \\
\text { 2009-2011 }\end{array}$ & $\begin{array}{l}13-15 q \\
2009 \\
\text { 2nd catch-up } \\
20-27+2012\end{array}$ & $\begin{array}{l}13-17 \text { ㅇ } \\
2008-2011\end{array}$ \\
\hline Estimated coverage & 2015 & 2015 & $2013 / 2014$ & 2015 & \\
\hline Three doses & $\begin{array}{l}77.4 \% \text { 웅 } \\
66.4 \% \text { o }\end{array}$ & $\begin{array}{l}41.9 \% \text { q } \\
28.1 \% \text { o }\end{array}$ & $86.7 \%$ & $82 \%$ & $\begin{array}{l}12-13 \text { years old } 90 \% \\
\text { Catch-up cohort } 66 \%\end{array}$ \\
\hline At least one dose & $\begin{array}{l}85.6 \% \text { ㅇ } \\
77 \% \text { o }\end{array}$ & $\begin{array}{l}62.8 \% \text { q } \\
49.8 \% \text { o }\end{array}$ & $91.1 \%$ & $90 \%$ & $>90 \%$ \\
\hline $\begin{array}{l}\text { Vaccine-type HPV } \\
\text { infection reduction }\end{array}$ & $\begin{array}{l}18-26 \text { years old } \\
3 x \text { dose } 86 \% \\
2 x \text { dose } 76 \%\end{array}$ & $\begin{array}{l}2010 \\
14-19+56 \% \\
2012 \\
14-19 \text { years old }+64 \% \\
20-24+34 \%\end{array}$ & $\begin{array}{l}16-18 \text { years old } \\
\text { HPV } 16 / 18 \\
\text { prevalence reduce } \\
\text { from } 19.1 \% \text { to } 6.5 \%\end{array}$ & Not available & $\begin{array}{l}\text { HPV } 16 / 18 \\
\text { prevalence reduce } \\
\text { from } 29.8 \% \text { to } 13.6 \%\end{array}$ \\
\hline $\begin{array}{l}\text { Genital warts (types } \\
6 / 11 \text { ) } \\
\text { Reduction }\end{array}$ & Up to $92 \%$ & $\begin{array}{l}<21 \text { years old } 34.8 \% \\
>21 \text { years old } 10 \%\end{array}$ & $\begin{array}{l}2 \mathrm{vHPV} \\
20.8 \% \\
4 \mathrm{vHPV}- \\
38.9 \% \text { \% } \\
30.2 \% \text { त }\end{array}$ & $\begin{array}{l}2013 \\
<18 \text { up to } 55.1 \% \\
<18 \text { years old }{ }^{\Uparrow} \text { up } \\
\text { to } 36.6 \%\end{array}$ & $\begin{array}{l}\text { Since 4VHPV vaccine } \\
\text { use, decline in wart } \\
\text { prescription (personal } \\
\text { communication, Kevin } \\
\text { Pollock, } 5 \text { January } \\
\text { 2017) }\end{array}$ \\
\hline $\begin{array}{l}\text { CIN/ } \\
\text { Adenocarcinoma } \\
\text { Reduction }\end{array}$ & $\begin{array}{l}\text { Low-grade } \\
34 \% \\
\text { High-grade } \\
47 \% \\
<20 \text { years old } 54 \% \\
20-24 \text { years old } 37 \%\end{array}$ & $\begin{array}{l}\text { HPV16/18 CIN2+ } \\
\text { qvaccinated }>24 \\
\text { months before } \\
\text { PAP versus } \\
\text { unvaccinated } \\
\text { q, adjusted } \\
\text { prevalence ratio of } \\
0.67\end{array}$ & Not available & $\begin{array}{l}\text { Atypia } \\
<18 \text { years old } \\
33.4 \% \text { (annual } \\
\text { percentage) } \\
18-20 \text { years old } \\
12.6 \% \\
\\
\text { CIN2+ } \\
18-20 \text { years old } \\
14 \%\end{array}$ & $\begin{array}{l}\text { CIN1 29\% } \\
\text { CIN2 50\% } \\
\text { CIN3 55\% }\end{array}$ \\
\hline $\begin{array}{l}\text { Screening program: } \\
\text { Type and interval age } \\
\text { commencement }\end{array}$ & $\begin{array}{l}\text { Cervical cytology } \\
\text { 18-69 every } 2 \text { years }\end{array}$ & $\begin{array}{l}\text { Cervical cytology } \\
21-65 \text { every } 3 \text { years }\end{array}$ & $\begin{array}{l}\text { Cervical cytology } \\
\text { 25-49 every } 3 \text { years } \\
\text { 50-64 every } 5 \text { years } \\
\text { January 2016: UK } \\
\text { National Screening } \\
\text { Committee } \\
\text { recommend HPV } \\
\text { primary screening } \\
\text { (to commence in } \\
\text { the near future) }\end{array}$ & $\begin{array}{l}\text { Cervical cytology } \\
\text { 23-49 every } 3 \text { years } \\
\text { 50-65 every } 5 \text { years }\end{array}$ & $\begin{array}{l}\text { Cervical cytology } \\
\text { 25-49 every } 3 \text { years } \\
50-64 \text { every } 5 \text { years }\end{array}$ \\
\hline Comments & $\begin{array}{l}1 \text { May } 2017 \text { to be } \\
\text { changed to HPV } \\
\text { DNA every } 5 \text { years } \\
\text { for } 25-74 \text { years old }\end{array}$ & & $\begin{array}{l}\text { Since } 2014, \\
\text { two-dose schedule } \\
<15 \text { years old } \\
>15 \text { years old on } \\
\text { initiation, three- } \\
\text { dose schedule }\end{array}$ & $\begin{array}{l}\text { Since } 2014 \text {, } \\
\text { two-dose schedule } \\
<15 \text { years old } \\
>15 \text { years old on } \\
\text { initiation, three-dose } \\
\text { schedule }\end{array}$ & $\begin{array}{l}\text { Screening prior to } \\
2013,20-60 \text { years old } \\
\text { every } 3 \text { years }\end{array}$ \\
\hline Additional references & 25,91 & $92-96$ & $97-100$ & 101,102 & 103,104 \\
\hline
\end{tabular}

Less than 15 years at the time of first dose: two-dose regimen of a prime and a boost separated by a minimum of 6 months ${ }^{73}$.

$2 \mathrm{vHPV}$, bivalent human papillomavirus vaccine; 4vHPV, quadrivalent human papillomavirus vaccine; 9vHPV, nonavalent human papillomavirus vaccine; CIN, cervical intraepithelial neoplasia; HPV, human papillomavirus; PAP, Papanicolaou test. 
noted a decrease of $8.1 \%$ in genital warts in the general population, and the highest decreases were in 16- to 22-year-old males and females between the pre- and post-vaccine era ${ }^{44}$. Australia, with its high vaccine coverage rates, reported the greatest worldwide decline, of up to $92 \%$ in the under- 21 age group ${ }^{37}$. Several studies have highlighted that the greatest efficacy of vaccination against genital warts was when the first dose of vaccine was given at a younger age ${ }^{44}$ with less of an effect at an older age ${ }^{40}$.

\section{Cervical cytology and histological abnormalities}

Genital warts have a short incubation period and hence this was the first disease reduction noted from vaccination. The second disease outcome to see reductions was cervical dysplasia, which has an intermediate incubation period (peak age of 26 to 30 years) ${ }^{45}$. Again, this was first reported in an ecological study in Victoria, Australia ${ }^{46}$ and was made possible because Australia had a HPV vaccine register, comprehensive cervical cytology reporting as well as the ability (following legislation) for the registers to be linked. Australia's national HPV vaccination programs have led to a $34 \%$ decline in low-grade and a $47 \%$ decline in high-grade cervical intraepithelial neoplasia (CIN) and adenocarcinoma in situ, and the largest reductions were in the vaccinated younger age group ${ }^{22,47}$. Women under the age of 20 had a prevalence decline from 10.9/1000 screened women to 5.0/1000 over a period of 10 years, and prevalence in 20to 24-year-olds decreased from $21.5 / 1000$ screened to $13.5 / 1000$ in a similar time period. In the over-30-year-old age group, the prevalence of high-grade CIN has continued to slowly rise ${ }^{48}$. Similar declines have been observed in Scotland and Denmark ${ }^{49-52}$ (Table 1). There are randomised controlled phase $2 / 3$ trials indicating that, despite diverse populations and geographical locations, HPV vaccines covering HPV16/18 provided some cross-protection against non-vaccine strain HPV and could protect women against cervical and non-cervical HPV-related infections ${ }^{53}$.

\section{Cervical cancer}

At present, it is too early to show clinical disease or populationbased disease reduction for cervical cancer, as this is a disease peaking in the mid-30s and mid-40s in Australia ${ }^{54}$, although the peak has shifted to the late 20 s to early 30 s in some countries ${ }^{55}$. One would expect to see reductions within the next few years in the under-30-year-olds, particularly in those countries with high coverage of catch-up programs extending to 26 years of age, such as Australia and Denmark.

Based on the PATRICIA trial (Papilloma Trial against Cancer in young Adults) of the $2 \mathrm{vHPV}$ vaccine, it has been estimated that with $50 \%$ vaccine coverage, there could be a worldwide reduction of cervical cancer incidence of 246,086 cases annually but that with $90 \%$ coverage, there could be up to 442,955 cases averted ${ }^{56}$. With the greater coverage provided by the nonavalent vaccine, it is proposed that with high coverage, $90 \%$ to $93 \%$ of all cervical cancers would be prevented ${ }^{57,58}$.

The incidence of non-cervical HPV-related cancers is generally low and peaks at a later age compared with cervical cancer ${ }^{59}$. Thus, more time and large population-based effectiveness studies with various cancers as endpoints will be required before impact can be determined. There are early data sets currently reviewing the implication of vaccine-type HPV reduction and the effect on persistent anal infections and intraepithelial neoplasia ${ }^{60}$.

\section{Impediments and challenges for the future}

Vaccine uptake and coverage. Although the effect of populationwide vaccination has been observed for 10 years, the reported findings may not accurately reflect future impact and this is for several reasons. Some countries have been slow to adopt HPV vaccination or vaccine coverage has been low (or both), even in high-income countries. Vaccine uptake rates in 13- to 17-year-olds in the USA in 2013 were $57 \%$ (one dose) and $38 \%$ (three doses) ${ }^{32}$. In Australia, between 2007 and 2015, vaccine uptake rates were $85.6 \%$ (one dose) and $77.4 \%$ (three doses) for females turning 15 years of age ${ }^{61}$. Successful strategies to increase coverage have included publically supported health promotion and missed-doses catch-up vaccine campaigns ${ }^{62}$, client reminders, recall programs, provider assessment and feedback interventions. Low- and middle-income countries often have a high HPV disease burden: however, only $15 \%$ of these countries have adopted a vaccination program ${ }^{18}$. Focusing on these countries and giving reassurance regarding vaccine safety will substantially impact HPV vaccination rates and outcomes ${ }^{63}$.

Safety. Concern regarding vaccine safety is an issue that often arises. The US Centers for Disease Control and Prevention (CDC), through the Vaccine Adverse Event Reporting System, classified only $7 \%$ of adverse events as serious from over 90 million doses of HPV vaccines. The CDC found no causal association between HPV vaccines and ovarian failure, Guillain-Barré syndrome or postural orthostatic tachycardia syndrome. Overall, HPV vaccines have a good safety profile, but ongoing monitoring will be required as $9 \mathrm{vHPV}$ vaccines have been introduced ${ }^{64-67}$. In Japan, poor or inappropriate information (or both), including reports on complex regional pain syndrome, has resulted in the government withdrawing support for HPV vaccination programs ${ }^{68-70}$. Despite comprehensive independent evaluations of safety ${ }^{71,72}$, including endorsement of safety by bodies such as the World Health Organization (WHO) $)^{73}$, the International Papillomavirus Society ${ }^{66}$ and the $\mathrm{CDC}^{74}$, the Japanese government has continued to refuse to re-implement population-wide vaccination ${ }^{69}$.

Ideal age for vaccination. In many respects, if the HPV vaccines could be administered in childhood, they could use infrastructure already in place for the Expanded Program on Immunization vaccines, as in general these see high uptake even in those countries with low resources. However, the immunity developed by HPV vaccination needs to be robust for several decades to ensure that infection does not occur when young people become sexually active and therefore to prevent diseases in the longer term. Although some studies have shown detectable neutralising antibodies 10 years after vaccination, there are not yet any data about antibody persistence beyond that ${ }^{22}$. It is currently believed that the antibody responses made by the vaccines are strong and long-lasting and that only small titres are in fact required for protection ${ }^{75}$.

Over the last 10 years, there have been changes in sexual behaviour, such as lowered median age of sexual debut, increased exposure from the increase in the number of sexual partners, and choice of orientation of sexual partner; however, these trends vary 
from country to country. The ability of vaccine programs in different countries to be flexible will allow these changes to be accounted for in the future. As shown in Table 1, different delivery programs/ routes for the vaccines result in different outcomes in different countries. A single worldwide approach is not appropriate, and programs need to be tailored to each country's population.

Dosing. New information regarding number of doses of vaccine necessary for long-lasting immunity is becoming available. The current WHO recommendation is that with respect to HPV-vaccine-relatedtype antibody responses, two doses of HPV vaccine for females 9 to 14 years old is non-inferior to three doses in adult women as long as the two doses are at least 6 months apart ${ }^{73}$. This decision was based largely on neutralising antibody outcome and more recent findings of reduced HPV-vaccine-type-related disease outcomes, but again good surveillance systems should be able to monitor impact on disease endpoints with longer time intervals from the point of vaccination. Furthermore, this may help to address concerns regarding reduced efficacy ${ }^{76}$ to ensure that a third dose could be administered if surveillance shows breakthrough disease. For females older than 15 years, those who are immunocompromised or HIV-positive, a three-dose regimen is still recommended ${ }^{73,77}$.

Gender-neutral approaches. Although females have been the primary target of HPV vaccine, extending the program towards males may have some benefit. A 2011 Australian study predicted that, based on the female-only vaccination program, there could be up to a $68 \%$ decrease in male HPV infections by 2050 and a $14 \%$ decrease in head, neck and anogenital cancers. The effect on oropharyngeal cancers is unclear ${ }^{78}$. This prediction is based on heterosexual relationships offering herd protection. A high-risk HPV group, men who have sex with men, are less likely to benefit from a female-only vaccination program ${ }^{79}$. A gender-neutral approach may not only reduce HPV-related diseases in males but also reduce the infection and transmission to females, ultimately reducing the pool of infectious virus in a community. Male vaccination would confer an even greater benefit in settings where female vaccination rates are low. Hence, vaccination of males has recently been incorporated into several national programs. Measuring vaccine effectiveness in the context of gender-neutral programs will bring further challenges $^{24}$.

Multivalent human papillomavirus vaccines. Some countries have implemented or have plans to commence the use of 9vHPV vaccines to offer protection against the additional five next most common oncogenic HPV types after HPV 16/18 in an effort to further improve health outcomes. This move is supported by studies which indicate potential cost savings and health benefits that could result from universal nonavalent vaccination programs ${ }^{16,80,81}$.

\section{Alternative vaccine policies: "HPV FASTER" potential to impact disease earlier}

Consideration for vaccinating women who are already sexually active but may not have been infected with all HPV types covered in the vaccines could well reduce the burden of disease more rapidly. This concept is based on data from phase 3 trials indicating that $2 \mathrm{vHPV}$ and $4 \mathrm{vHPV}$ vaccines are efficacious, immunogenic and safe in women ages 26 to 45 years old with a $90 \%$ vaccine efficacy in protection against cervical pre-cancer in HPV-DNAnegative women (regardless of serostatus) and 50\% vaccine efficacy in women who had previously been exposed to $\mathrm{HPV}^{82-84}$. Moreover, in trials in younger women, it was shown that vaccines were not efficacious when a woman was HPV-positive for a particular type ${ }^{85}$, although it was likely for women who were HPV-negative but antibody-positive from natural infection that they would gain efficacy against later disease ${ }^{86,87}$. The importance of a coordinated screening and vaccination program cannot be overlooked and this has prompted the HPV-FASTER concept. This protocol intends to offer women up to the age of 45 years HPV vaccination and incorporates HPV testing after the age of 30 for screening, with ongoing follow-up and early management of high-risk HPVpositive women. Further studies will be required to investigate the acceptability and feasibility of such an approach, most appropriate cut-off age of offering vaccination, ideal screening commencement, cessation and interval times to refine the protocol ${ }^{88}$.

Surveillance. A necessary condition for accurately monitoring the impact and effectiveness of vaccine programs is the existence of diligent and ongoing surveillance ${ }^{89}$. For HPV, this requires surveillance of HPV vaccination coverage and safety, HPV infection genoprevalence, cervical dysplasia incidence, cervical (as well as other anogenital and oropharyngeal cancer, ideally with genotyping of cancers) cancer registries, as well as surveillance for non-cancer outcomes such as warts and RRPs. Ideally, this would include the ability for the various data sources to be linked. Encouragement in participation in screening programs is essential, particularly as new cervical screening programs that incorporate DNA testing as the primary screen usually have longer intervals between screens compared with those with cervical cytology as primary. Also, the vaccinated population may not recognise that, despite vaccination, there is a need for ongoing monitoring. With so many changes, education of the community, clinicians and women in particular is critical.

\section{Conclusions}

Overall, the implementation of HPV vaccine public health programs has resulted in major decreases in vaccine-type HPV infection prevalence as well as associated disease incidence in countries that have introduced them. Administration of vaccines is ideally done prior to sexual debut for both males and females for the greatest impact. Herd and cross-protection contribute further to the impact of the vaccines. More time for observation is required to determine the effect on cancer rates, as carcinomas develop decades after infection acquisition. Although we have the tools to markedly impact HPV-related disease, we also face the challenge of ensuring that all young people, regardless of their geography, social status, or immunocompromised status, are eligible for and can access these vaccines. To observe the vaccine impact and effectiveness of national HPV vaccination programs, support is required from accurate vaccine uptake surveillance, preferably through vaccine registers in addition to genoprevalence and HPV-related disease endpoint surveillance, including cancer registries and pre-cancer screening programs. 


\section{Competing interests}

SG has received speaking fees from Merck Sharp \& Dohme (MSD) and Sanofi Pasteur MSD for work performed in her personal time. Merck paid for her travel and accommodation to present at HPV Advisory Board meetings. Lai-yang Lee declares that she has no competing interests.

\section{Grant information}

SG has received grants to her institution from the Commonwealth Department of Health for HPV genoprevalence surveillance postvaccination, Merck and GlaxoSmithKline to perform phase 3 clinical vaccine trials, Merck to evaluate HPV in RRP post-vaccination program, Seqirus Australia for funding of the Australian Cervical Cancer Typing Study, and the Victoria Cancer Agency for a study on monitoring and effectiveness of the Australian cervical cancer program, a translation to reduction in vaccine-related HPV infection and pre-cancerous cervical lesions study (the Vaccine Against Cervical Cancer Impact and Effectiveness study) plus a study on associations and typing of early-onset cancers in young women.

\section{Acknowledgements}

We would like to thank David Mesher, Kevin Pollock, Charles Lacey and Susanne Krüger Kjaer for their prompt replies, insightful comments and information about their respective countries' vaccine programs.
1. Forman D, de Martel C, Lacey CJ, et al:: Global burden of human papillomavirus and related diseases. Vaccine. 2012; 30(Suppl 5): F12-23. PubMed Abstract | Publisher Full Text

2. Walboomers JM, Jacobs MV, Manos MM, et al:: Human papillomavirus is a necessary cause of invasive cervical cancer worldwide. J Pathol. 1999; 189(1): $12-9$.

PubMed Abstract | Publisher Full Text

3. Giuliano AR, Harris R, Sedjo RL, et al.: Incidence, prevalence, and clearance of type-specific human papillomavirus infections: The Young Women's Health Study. J Infect Dis. 2002; 186(4): 462-9. PubMed Abstract | Publisher Full Text

4. Monsonego J, Bosch FX, Coursaget $\mathrm{P}$, et al.: Cervical cancer control, priorities and new directions. Int J Cancer. 2004; 108(3): 329-33.

PubMed Abstract | Publisher Full Text

5. Wright TC Jr: Natural history of HPV infections. J Fam Pract. Quadrant Healthcom, Inc; 2009; 58(9 Suppl HPV): S3-7. PubMed Abstract

6. Gravitt PE: Evidence and impact of human papillomavirus latency. Open Virol $\mathrm{J}$ 2012; 6(Suppl 2): 198-203.

PubMed Abstract | Publisher Full Text | Free Full Text

7. Hampton T: Nobel Prize honors HIV, HPV discoveries. JAMA. 2008; 300(18): 2109. PubMed Abstract | Publisher Full Text

8. Clifford GM, Smith JS, Plummer M, et al:: Human papillomavirus types in invasive cervical cancer worldwide: a meta-analysis. Br J Cancer. 2003; 88(1): 63-73. PubMed Abstract | Publisher Full Text | Free Full Text

9. World Health Organisation: Media Centre: Human Papillomavirus(HPV) and cervical cancer. 2016. Reference Source

10. F Garland SM, Steben M, Sings HL, et al:: Natural history of genital warts: analysis of the placebo arm of 2 randomized phase III trials of a quadrivalent human papillomavirus (types $6,11,16$, and 18 ) vaccine. J Infect Dis. 2009; 199(6): 805-14.

PubMed Abstract | Publisher Full Text | F1000 Recommendation

11. Somers GR, Tabrizi SN, Borg AJ, et al.: Juvenile laryngeal papillomatosis in a pediatric population: a clinicopathologic study. Pediatr Pathol Lab Med. 1997; 17(1): 53-64.

PubMed Abstract | Publisher Full Text

12. Wheeler $\mathrm{CM}$, Castellsagué $\mathrm{X}$, Garland $\mathrm{SM}$, et al:: Cross-protective efficacy of HPV-16/18 AS04-adjuvanted vaccine against cervical infection and precancer caused by non-vaccine oncogenic HPV types: 4-year end-of-study analysis of the randomised, double-blind PATRICIA trial. Lancet Oncol. 2012; 13(1): 100-10. PubMed Abstract | Publisher Full Text

13. F Lehtinen M, Paavonen J, Wheeler CM, et al:: Overall efficacy of HPV-16/18 AS04-adjuvanted vaccine against grade 3 or greater cervical intraepithelial neoplasia: 4-year end-of-study analysis of the randomised, double-blind PATRICIA trial. Lancet Oncol. 2012; 13(1): 89-99. PubMed Abstract | Publisher Full Text | F1000 Recommendation

14. F Garland SM, Hernandez-Avila M, Wheeler CM, et al:: Quadrivalent vaccine against human papillomavirus to prevent anogenital diseases. $N$ Engl J Med.
2007; 356(19): 1928-43.

PubMed Abstract | Publisher Full Text | F1000 Recommendation

15. F FUTURE II Study Group: Quadrivalent vaccine against human papillomavirus to prevent high-grade cervical lesions. N Engl J Med. 2007; 356(19): 1915-27.

PubMed Abstract | Publisher Full Text | F1000 Recommendation

16. Joura EA, Giuliano AR, Iversen OE, et al:: A 9-valent HPV vaccine against infection and intraepithelial neoplasia in women. N Engl J Med. 2015; 372(8): 711-23.

PubMed Abstract | Publisher Full Text

17. F Brisson M, Bénard É, Drolet M, et al.: Population-level impact, herd mmunity, and elimination after human papillomavirus vaccination: A systematic review and meta-analysis of predictions from transmissiondynamic models. Lancet Public Health. 2016; 1(1): e8-e17. Publisher Full Text | F1000 Recommendation

18. F Drolet M, Bénard E, Boily MC, et al:: Population-level impact and herd effects following human papillomavirus vaccination programmes: a systematic review and meta-analysis. Lancet Infect Dis. 2015; 15(5): 565-80. PubMed Abstract | Publisher Full Text | Free Full Text | F1000 Recommendation

19. F Poljak M, Kocjan BJ, Oštrbenk A, et al.: Commercially available molecula tests for human papillomaviruses (HPV): 2015 update. J Clin Virol. 2016; 76(Suppl 1): S3-S13.

PubMed Abstract | Publisher Full Text | F1000 Recommendation

20. Snijders PJ, van den Brule AJ, Meijer CJ: The clinical relevance of human papillomavirus testing: relationship between analytical and clinical sensitivity. $J$ Pathol. 2003; 201(1): 1-6.

PubMed Abstract | Publisher Full Text

21. Pagliusi SR, Garland SM: International standard reagents for HPV detection. Dis Markers. 2007; 23(4): 283-96.

PubMed Abstract | Publisher Full Text | Free Full Text

22. Garland SM, Kjaer SK, Muñoz N, et al.: Impact and Effectiveness of the Quadrivalent Human Papillomavirus Vaccine: A Systematic Review of 10 Years of Real-world Experience. Clin Infect Dis. 2016; 63(4): 519-27. PubMed Abstract | Publisher Full Text | Free Full Text

23. Garland SM, Skinner SR, Brotherton JM: Adolescent and young adult HPV vaccination in Australia: achievements and challenges. Prev Med. 2011; 53(Suppl 1): S29-35. PubMed Abstract | Publisher Full Text

24. Garland SM, Molesworth EG, Machalek DA, et al.: How to best measure the effectiveness of male human papillomavirus vaccine programmes? Clin Microbiol Infect. 2015; 21(9): 834-41. PubMed Abstract | Publisher Full Text

25. National HPV Vaccination Program Register: HPV vaccination coverage by dose number (Australia) for males by age group in mid 2014. [cited 2017 Jan 8]. Reference Source

26. F Brotherton JM, Liu B, Donovan B, et al:: Human papillomavirus (HPV) vaccination coverage in young Australian women is higher than previously estimated: independent estimates from a nationally representative mobile 
phone survey. Vaccine. 2014; 32(5): 592-7.

PubMed Abstract | Publisher Full Text | F1000 Recommendation

27. F Tabrizi SN, Brotherton JM, Kaldor JM, et al.: Fall in human papillomavirus prevalence following a national vaccination program. J Infect Dis. 2012; 206(11): 1645-51.

PubMed Abstract | Publisher Full Text | F1000 Recommendation

28. Tabrizi SN, Brotherton JM, Kaldor JM, et al:: Assessment of herd immunity and cross-protection after a human papillomavirus vaccination programme in Australia: a repeat cross-sectional study. Lancet Infect Dis. 2014; 14(10): 958-66.

PubMed Abstract | Publisher Full Text

29. Machalek DA, Chow EP, Garland SM, et al:: Human Papillomavirus Prevalence in Unvaccinated Heterosexual Men After a National Female Vaccination Program. $J$ Infect Dis. 2017; 215(2): 202-8.

PubMed Abstract | Publisher Full Text

30. F Kavanagh K, Pollock KG, Potts A, et al:: Introduction and sustained high coverage of the HPV bivalent vaccine leads to a reduction in prevalence of HPV 16/18 and closely related HPV types. Br J Cancer. 2014; 110(11): 2804-11. PubMed Abstract | Publisher Full Text | Free Full Text | F1000 Recommendation

31. F Markowitz LE, Hariri S, Lin C, et al.: Reduction in human papillomavirus (HPV) prevalence among young women following HPV vaccine introduction in the United States, National Health and Nutrition Examination Surveys, 2003-2010. J Infect Dis. 2013; 208(3): 385-93.

PubMed Abstract | Publisher Full Text | F1000 Recommendation

32. F Markowitz LE, Liu G, Hariri S, et al.: Prevalence of HPV After Introduction of the Vaccination Program in the United States. Pediatrics. 2016; 137(3): e20151968.

PubMed Abstract | Publisher Full Text | F1000 Recommendation

33. F Berenson AB, Laz TH, Rahman M: Reduction in Vaccine-Type Human Papillomavirus Prevalence Among Women in the United States, 2009-2012. $J$ Infect Dis. 2016; 214(12): 1961-4.

PubMed Abstract | Publisher Full Text | F1000 Recommendation

34. Kjaer SK, Tran TN, Sparen $P$, et al:: The burden of genital warts: a study of nearly 70,000 women from the general female population in the 4 Nordic countries. J Infect Dis. 2007; 196(10): 1447-54

PubMed Abstract | Publisher Full Tex

35. F Donovan B, Franklin N, Guy R, et al:: Quadrivalent human papillomavirus vaccination and trends in genital warts in Australia: analysis of national sentinel surveillance data. Lancet Infect Dis. 2011; 11(1): 39-44. PubMed Abstract | Publisher Full Text | F1000 Recommendation

36. F Read TR, Hocking JS, Chen MY, et al:: The near disappearance of genital warts in young women 4 years after commencing a national human papillomavirus (HPV) vaccination programme. Sex Transm Infect. 2011; 87(7): 544-7.

PubMed Abstract | Publisher Full Text | F1000 Recommendation

37. F Ali H, Donovan B, Wand H, et al.: Genital warts in young Australians five years into national human papillomavirus vaccination programme: national surveillance data. BMJ. 2013; 346: 2032 .

PubMed Abstract | Publisher Full Text | F1000 Recommendation

38. Howell-Jones R, Soldan K, Wetten S, et al.: Declining genital Warts in young women in england associated with HPV 16/18 vaccination: an ecological study. J Infect Dis. 2013; 208(9): 1397-403.

PubMed Abstract | Publisher Full Text | Free Full Text

39. Szarewski A, Skinner SR, Garland SM, et al:: Efficacy of the HPV-16/18 AS04adjuvanted vaccine against low-risk HPV types (PATRICIA randomized trial): an unexpected observation. J Infect Dis. 2013; 208(9): 1391-6. PubMed Abstract | Publisher Full Text | Free Full Text

40. F Dochez C, Bogers JJ, Verhelst R, et al:: HPV vaccines to prevent cervical cancer and genital warts: an update. Vaccine. 2014; 32(14): 1595-601. PubMed Abstract | Publisher Full Text | F1000 Recommendation

41. Baandrup L, Blomberg M, Dehlendorff C, et al.: Significant decrease in the incidence of genital warts in young Danish women after implementation of a national human papillomavirus vaccination program. Sex Transm Dis. 2013; 40(2): 130-5.

PubMed Abstract

42. F Bollerup S, Baldur-Felskov B, Blomberg M, et al.: Significant Reduction in the Incidence of Genital Warts in Young Men 5 Years into the Danish Human Papillomavirus Vaccination Program for Girls and Women. Sex Transm Dis. 2016; 43(4): 238-42.

PubMed Abstract | Publisher Full Text | F1000 Recommendation

43. Blomberg M, Dehlendorff C, Munk C, et al:: Strongly decreased risk of genital warts after vaccination against human papillomavirus: nationwide follow-up of vaccinated and unvaccinated girls in Denmark. Clin Infect Dis. 2013; 57(7): 929-34.

PubMed Abstract | Publisher Full Text

44. F Dominiak-Felden G, Gobbo C, Simondon F: Evaluating the Early Benefit of Quadrivalent HPV Vaccine on Genital Warts in Belgium: A Cohort Study. PLOS One. 2015; 10(7): e0132404.

PubMed Abstract | Publisher Full Text | Free Full Text | F1000 Recommendation

45. Australian Government. Australian Insititue of Health and Welfare: Cervical screening in Australia 2013-2014. [cited 2017 Jan 8].

Reference Source
46. Brotherton JM, Fridman M, May CL, et al.: Early effect of the HPV vaccination programme on cervical abnormalities in Victoria, Australia: an ecological study. Lancet. 2011; 377(9783): 2085-92.

PubMed Abstract | Publisher Full Text

47. Gertig DM, Brotherton JM, Budd AC, et al:: Impact of a population-based HPV vaccination program on cervical abnormalities: a data linkage study. $B M C$ Med. 2013; 11: 227.

PubMed Abstract | Publisher Full Text | Free Full Text

48. Brotherton JM, Saville AM, May CL, et al:: Human papillomavirus vaccination is changing the epidemiology of high-grade cervical lesions in Australia. Cancer Causes Control. 2015; 26(6): 953-4.

PubMed Abstract | Publisher Full Tex

49. F Pollock KG, Kavanagh K, Potts A, et al.: Reduction of low- and high-grade cervical abnormalities associated with high uptake of the HPV bivalent vaccine in Scotland. Br J Cancer. 2014; 111(9): 1824-30.

PubMed Abstract | Publisher Full Text | Free Full Text | F1000 Recommendation

50. F Baldur-Felskov B, Dehlendorff C, Munk C, et al.: Early impact of human papillomavirus vaccination on cervical neoplasia--nationwide follow-up of young Danish women. J Natl Cancer Inst. 2014; 106(3): djt460.

PubMed Abstract | Publisher Full Text | F1000 Recommendation

51. F Baldur-Felskov B, Dehlendorff C, Junge J, et al.: Incidence of cervical lesions in Danish women before and after implementation of a national HPV vaccination program. Cancer Causes Control. 2014; 25(7): 915-22. PubMed Abstract | Publisher Full Text | F1000 Recommendation

52. F Baldur-Felskov B, Munk C, Nielsen TS, et al:: Trends in the incidence of cervical cancer and severe precancerous lesions in Denmark, 1997-2012. Cancer Causes Control. 2015; 26(8): 1105-16.

PubMed Abstract | Publisher Full Text | F1000 Recommendation

53. F Skinner SR, Apter D, De Carvalho N, et al:: Human papillomavirus (HPV) 16/18 AS04-adjuvanted vaccine for the prevention of cervical cancer and HPV-related diseases. Expert Rev Vaccines. 2016; 15(3): 367-87. PubMed Abstract | F1000 Recommendation

54. Australian Government Cancer Australia: Cervical cancer in Australia. [cited 2017 Jan 8].

Reference Source

55. Cancer Research UK: Cervical cancer incidence statistics. [cited 2017 Mar 21]. Reference Source

56. F van Kriekinge G, Castellsague X, Cibula D, et al.: Estimation of the potentia overall impact of human papillomavirus vaccination on cervical cancer cases and deaths. Vaccine. 2014; 32(6): 733-9.

PubMed Abstract | Publisher Full Text | F1000 Recommendation

57. F Riethmuller D, Jacquard A, Lacau St Guily J, et al:: Potential impact of a nonavalent HPV vaccine on the occurrence of HPV-related diseases in France. BMC Public Health. 2015; 15: 453.

PubMed Abstract | Publisher Full Text | Free Full Text | F1000 Recommendation

58. F Luckett R, Feldman S: Impact of 2-, 4- and 9-valent HPV vaccines on morbidity and mortality from cervical cancer. Hum Vaccin Immunother. 2016; 12(6): 1332-42.

PubMed Abstract | Publisher Full Text | Free Full Text | F1000 Recommendation

59. F Buchanan TR, Graybill WS, Pierce JY: Morbidity and mortality of vulvar and vaginal cancers: Impact of 2-, 4-, and 9-valent HPV vaccines. Hum Vaccin Immunother. 2016; 12(6): 1352-6.

PubMed Abstract | Publisher Full Text | Free Full Text | F1000 Recommendation

60. F Stier EA, Chigurupati NL, Fung L: Prophylactic HPV vaccination and anal cancer. Hum Vaccin Immunother. 2016; 12(6): 1348-51. PubMed Abstract | Free Full Text | F1000 Recommendation

61. National HPV Vaccination Program Register:HPV Vaccination Coverage. [cited 2017 Jan 13] Reference Source

62. Garland SM: The Australian experience with the human papillomavirus vaccine. Clin Ther. 2014; 36(1): 17-23. PubMed Abstract | Publisher Full Text

63. Oliver K, Frawley A, Garland E: HPV vaccination: Population approaches for improving rates. Hum Vaccin Immunother. 2016; 12(6): 1589-93. PubMed Abstract | Publisher Full Text | Free Full Text

64. F Gee J, Weinbaum C, Sukumaran L, et al:: Quadrivalent HPV vaccine safety review and safety monitoring plans for nine-valent HPV vaccine in the United States. Hum Vaccin Immunother. 2016; 12(6): 1406-17.

PubMed Abstract | Publisher Full Text | Free Full Text | F1000 Recommendation

65. F Naud PS, Roteli-Martins CM, Carvalho NS, et al.: Sustained efficacy, immunogenicity, and safety of the HPV-16/18 AS04-adjuvanted vaccine: final analysis of a long-term follow-up study up to 9.4 years post-vaccination. Hum Vaccin Immunother. 2014; 10(8): 2147-62.

PubMed Abstract | Publisher Full Text | Free Full Text | F1000 Recommendation

66. Garland SM, Stanley M, Brotheron J, et al:: IPVS Policy statement on safety of HPV vaccines. Papillomavirus Res. 2016; 2: 9-10. Publisher Full Text

67. Centers for Disease Control and Prevention: Frequently asked Questions about HPV Vaccine Safety. [cited 2017 Mar 13].

Reference Source

68. Larson HJ, Wilson R, Hanley S, et al:: Tracking the global spread of vaccine 
sentiments: the global response to Japan's suspension of its HPV vaccine recommendation. Hum Vaccin Immunother. 2014; 10(9): 2543-50. PubMed Abstract | Publisher Full Text | Free Full Text

69. Tanaka $Y$, Ueda $Y$, Egawa-Takata $T$, et al:: Outcomes for girls without HPV vaccination in Japan. Lancet Oncol. 2016; 17(7): 868-9. PubMed Abstract | Publisher Full Text

70. Hanley SJ, Yoshioka E, Ito Y, et al:: HPV vaccination crisis in Japan. Lancet. 2015; 385(9987): 2571.

PubMed Abstract | Publisher Full Text

71. Vichnin M, Bonanni P, Klein NP, et al.: An Overview of Quadrivalent Human Papillomavirus Vaccine Safety: 2006 to 2015. Pediatr Infect Dis J. 2015; 34(9): 983-91.

PubMed Abstract | Publisher Full Text

72. Safety of HPV Vaccines: Global Vaccine Safety. [cited 2017 Jan 8]. Reference Source

73. World Health Organisation: Immunisation, Vaccines and Biologicals: Human Papillomavirus (HPV). 2016, [cited 2017 Jan 3] Reference Source

74. Centers for Disease Control and Prevention: Human Papillomavirus (HPV) Vaccine Safety. [cited 2017 Jan 14]. Reference Source

75. F Stanley M: Immune responses to human papillomavirus. Vaccine. 2006; 24(Suppl 1): S16-22. PubMed Abstract | Publisher Full Text | F1000 Recommendation

76. Basu P, Bhatla N, Ngoma T, et al.: Less than 3 doses of the HPV vaccine-Review of efficacy against virological and disease end points. Hum Vaccin Immunother. 2016; 12(6): 1394-402.

PubMed Abstract | Publisher Full Text | Free Full Text

77. Australian Technical Advisory Group on Immunisation (ATAGI): The Australian Immunisation Handbook 10th ed (2016 update). Canberra: Australian Government Department of Health. 2016. Reference Source

78. Smith MA, Lew JB, Walker RJ, et al:: The predicted impact of HPV vaccination on male infections and male HPV-related cancers in Australia. Vaccine. 2011. 29(48): 9112-22.

PubMed Abstract | Publisher Full Text

79. F Smith MA, Canfell K: Incremental benefits of male HPV vaccination: accounting for inequality in population uptake. PLoS One. 2014; 9(8): e101048. PubMed Abstract | Publisher Full Text | Free Full Text | F1000 Recommendation

80. F Largeron N, Petry KU, Jacob J, et al:: An estimate of the public health impact and cost-effectiveness of universal vaccination with a 9-valent HPV vaccine in Germany. Expert Rev Pharmacoecon Outcomes Res. 2017; 17(1): 85-98. PubMed Abstract | Publisher Full Text | F1000 Recommendation

81. F Drolet M, Laprise JF, Boily MC, et al:: Potential cost-effectiveness of the nonavalent human papillomavirus (HPV) vaccine. Int J Cancer. 2014; 134(9): 2264-8.

PubMed Abstract | Publisher Full Text | F1000 Recommendation

82. Skinner SR, Szarewski A, Romanowski B, et al.: Efficacy, safety, and immunogenicity of the human papillomavirus 16/18 AS04-adjuvanted vaccine in women older than 25 years: 4-year interim follow-up of the phase 3 , doubleblind, randomised controlled VIVIANE study. Lancet. 2014; 384(9961): 2213-27. PubMed Abstract | Publisher Full Text

83. Wheeler CM, Skinner SR, Del Rosario-Raymundo MR, et al.: Efficacy, safety, and immunogenicity of the human papillomavirus 16/18 AS04-adjuvanted vaccine in women older than 25 years: 7-year follow-up of the phase 3, double-blind, randomised controlled VIVIANE study. Lancet Infect Dis. 2016; 16(10): 1154-68. PubMed Abstract | Publisher Full Tex

84. F Munoz N, Manalastas R Jr, Pitisuttithum P, et al.: Safety, immunogenicity, and efficacy of quadrivalent human papillomavirus (types $6,11,16,18$ ) recombinant vaccine in women aged $24-5$ years: a randomised, double-blind trial. Lancet. 2009; 373(9679): 1949-57.

PubMed Abstract | Publisher Full Text | F1000 Recommendation

85. Haupt RM, Wheeler CM, Brown DR, et al:: Impact of an HPV6/11/16/18 L1 viruslike particle vaccine on progression to cervical intraepithelial neoplasia in seropositive women with HPV16/18 infection. Int J Cancer. 2011; 129(11): 2632-42.

PubMed Abstract | Publisher Full Text

86. Olsson SE, Kjaer SK, Sigurdsson K, et al.: Evaluation of quadrivalent HPV $6 / 11 / 16 / 18$ vaccine efficacy against cervical and anogenital disease in subjects with serological evidence of prior vaccine type HPV infection. Hum Vaccin. 2009; 5(10): 696-704.

PubMed Abstract | Publisher Full Text

87. Szarewski A, Poppe WA, Skinner SR, et al.: Efficacy of the human papillomavirus (HPV)-16/18 AS04-adjuvanted vaccine in women aged 15-25 years with and without serological evidence of previous exposure to HPV16/18. Int J Cancer. 2012; 131(1): 106-16.

PubMed Abstract Publisher Full Text

88. Bosch FX, Robles C, Díaz M, et al:: HPV-FASTER: broadening the scope for prevention of HPV-related cancer. Nat Rev Clin Oncol. 2016; 13(2): 119-32. PubMed Abstract | Publisher Full Text

89. Brotherton JM, Kaldor JM, Garland SM: Monitoring the control of human papillomavirus (HPV) infection and related diseases in Australia: towards a national HPV surveillance strategy. Sex Health. 2010; 7(3): 310-9. PubMed Abstract | Publisher Full Text

90. Stubbs R: Public Health England Screening-HPV primary screening in the cervical screening programme. [cited 2017 Mar 13]. Reference Source

91. ICO Information Centre on HPV and Cancer. hpvcentre.net. [cited 2017 Jan 13]. Reference Source

92. Centers for Disease Control and Prevention: Human Papillomavirus (HPV). [cited 2017 Jan 8]

Reference Source

93. Centers for Disease Control and Prevention: Human Papillomavirus(HPV)ACIP Vaccine Recommendations. [cited 2017 Jan 13]. Reference Source

94. National, Regional State, and Selected Local Area Vaccination Coverage Among Adolescents Aged 13-17years-United States 2015 MMWR Aug 262016. [cited 2017 Jan 13] Reference Source

95. NIH National Cancer Institute: Human Papillomavirus (HPV) Vaccine. 2016, [cited 2017 Jan 13]. Reference Source

96. Powell SE, Hariri S, Steinau M, et al:: Impact of human papillomavirus (HPV) vaccination on HPV 16/18-related prevalence in precancerous cervical lesions. Vaccine. 2012; 31(1): 109-13. PubMed Abstract | Publisher Full Text

97. NHS: HPV Vaccine. 2014, [cited 2017 Jan 13]. Reference Source

98. NHS: Cervical screening. 2015, [cited 2017 Jan 13]. Reference Source

99. Public Health England: Human Papillomavirus (HPV) Vaccine Coverage in England, 2008/09 to 2013/14, A review of the full six years of the three-dose schedule. 2015, [cited 2017 Jan 13]. Reference Source

100. Public Health England: HPR volume 10 issue 22:news (8July). [cited 2017 Jan 13]. Reference Source

101. ICO Information Centre on HPV and Cancer: Human Papillomavirus and Related Diseases Report: Denmark, December 15 2016. [cited 2017 Jan 8]. Reference Source

102. Blomberg M, Dehlendorff C, Sand C, et al:: Dose-Related Differences in Effectiveness of Human Papillomavirus Vaccination Against Genital Warts: A Nationwide Study of 550,000 Young Girls. Clin Infect Dis. 2015; 61(5): 676-82. PubMed Abstract | Publisher Full Text

103. Immunisation Scotland: HPV Vaccine. 2016, [cited 2017 Jan 13]. Reference Source

104. Information Services Division Publication Report: HPV Immunisation Statistics Scotland, School year 2015/2016. 2016, [cited 2017 Jan 13] Reference Source 


\section{Open Peer Review}

\section{Current Peer Review Status:}

\section{Editorial Note on the Review Process}

Faculty Reviews are review articles written by the prestigious Members of Faculty Opinions. The articles are commissioned and peer reviewed before publication to ensure that the final, published version is comprehensive and accessible. The reviewers who approved the final version are listed with their names and affiliations.

\section{The reviewers who approved this article are:}

\section{Version 1}

\section{Mark Jit}

${ }^{1}$ Department of Infectious Disease Epidemiology, London School of Hygiene and Tropical Medicine, London, UK

2 National Infections Service - Colindale, Public Health England, London, UK

Competing Interests: No competing interests were disclosed.

\section{Linda Niccolai}

Yale School of Public Health, New Haven, CT, USA

Competing Interests: No competing interests were disclosed.

\section{Eileen Dunne}

${ }^{1}$ Division of HIV/AIDS Prevention, Centers for Disease Control and Prevention, Atlanta, Georgia, USA

2 HIV/STD Research Program, Thailand MOPH CDC Collaboration, Bangkok, Thailand

Competing Interests: No competing interests were disclosed.

The benefits of publishing with F1000Research:

- Your article is published within days, with no editorial bias

- You can publish traditional articles, null/negative results, case reports, data notes and more

- The peer review process is transparent and collaborative

- Your article is indexed in PubMed after passing peer review

- Dedicated customer support at every stage

For pre-submission enquiries, contact research@f1000.com 